\title{
CREATION OF STATES IN NIGERIA, 1967-1996: DECON- STRUCTING THE HISTORY AND POLITICS
}

\author{
Ejitu N. Ota, Ph.D \\ Department of History and International Relations, Abia State University, Uturu, Nigeria \\ Chinyere S. Ecoma, Ph.D \\ Department of History and International Relations, Veritas University, Abuja, Nigeria \\ Chiemela Godwin Wambu, Ph.D \\ Department of History and International Relations, Abia State University, Uturu, Nigeria \\ E-mail: *ecomachinyere@yahoo.com
}

\begin{abstract}
One of the lasting legacies of military rule in Nigeria is the creation of states. This started in 1967 when Yakubu Gowon, the then military Head of State (1967-1975) created twelve states to replace the existing regional arrangement. Almost every subsequent military regime has latched on this precedent to create states, the last being that of General Sani Abacha. In all, political, more than any other consideration informed the creation of states. All the exercises in state creation have also reflected and sustained the numerical dominance of the former northern region over the former eastern and western regions. Using primary and secondary sources in its methodology, this paper historicises state creation in Nigeria and concludes that state creation by military Heads of State since 1967 achieved the prime objective of political, economic and numerical domination of the south by the north. This translates to allocation of enormously higher resources to the north than the south which generates most of the national resources. The paper opines that restructuring the Nigerian state could be a lasting elixir to the ill feelings among ethnic minorities in the country.
\end{abstract}

Key words: States, North, South, Ethno-religious, Military regimes.

\section{INTRODUCTION}

Nigeria became a single country in 1914 following the amalgamation of the then northern and southern protectorates by Frederick Lugard, on behalf of the British Crown. Later in 1949 and as a result of the promulgation of the Richard's Constitution, the country was divided into three regions, namely, the eastern region, the northern region and the western region. Each of these comprised a multiplicity of ethnic groups, though the Igbo, the Hausa-Fulani and the Yoruba were numerically and politically the dominant ethnic groups in the east, north and west respectively. This led to fears of domination and agitations for separate regions by some ethnic minorities in the various regions. For instance, there was the Calabar-Ogoja-River (COR) State Movement in the east; there were also the Benin and Delta Movements in the western region, as well as the Middle Belt Movement in northern Nigeria. The utmost desire of these groups was to be free from the perceived domination of their numerically stronger partners. It was in reaction to such agitations that the British colonial regime set up the Henry Willinks Commission in 1958. Its mandate was to study the fears of Nigeria's ethnic minorities and suggest ways to allay such fears, including the creation of separate states for them. However, the Commission did not recommend the creation of states for ethnic minority groups in Nigeria. On the contrary, it held the view that there were other alternatives for addressing their fears, including the entrenchment of human rights, the establishment of special development authorities, and the sustained implementation of 
democratic practices (Azikiwe, 1943; Awolowo, 1947: 54). Also, both Nnamdi Azikiwe and Obafemi Awolowo did, at various times, suggest the creation of states during the colonial era. While Azikiwe suggested the use of existing provinces, Awolowo advocated ethnicity as the solution (Olusanya, 1999: 536-537; Ojiako, 1981: 40-46).

In 1963, the mid-western region was carved out from the western region. By this move, there was an alteration of the existing tripodal regional structure which had existed in the country during the colonial era. Further territorial reconfigurations in Nigeria had to wait till 1967 when Yakubu Gowon's military government jettisoned the regional arrangement. Instead, a twelve-state structure was introduced. Ten years later in 1976, following the overthrow of the Gowon regime by Murtala Mohammed, the twelve-state structure was increased to nineteen states. When Ibrahim Babaginda became Nigeria's fourth military ruler in 1985, he created two additional states, making it a total of nineteen states in the country. Six new states were created by his successor General Sani Abacha, in 1996. Thus, there are at present, thirty-six states in Nigeria. Ironically, the agitations for more states by different groups in the country have not abated. Instead, they have increased in intensity.

\section{STATE CREATION SINCE 1967}

Between 1960 and 1966, Nigeria still operated the regional arrangement. However, between 1967 and 1996, the country had to be split into thirty-six States. The first state creation exercise was undertaken by the regime of Yakubu Gowon in 1967. Prior to Gowon's ascension to power, Aguiyi Ironsi was Nigeria's first military Head of State but following his assassination in July 1966, Gowon became the new military ruler of the country. He dissolved the four regions in the country and subsequently created twelve States on May 5, 1967. Six States were carved out from the former northern region. These were: the North-Western State, the North-Eastern State, Kano State, North Central State, Benue-Plateau State and Kwara State. The former western region was split into two States: the Western State and Lagos State. The former mid-western region became the Mid-Western State, while the former eastern region had three new States carved out from it. These were the East Central State, Rivers State and the South-Eastern State. Another state creation exercise took place in 1976 following the ouster of Yakubu Gowon in a military coup led by Murtala Mohammed. On assumption of office, he (Murtala Mohammed) created the following States: Anambra, Bauchi, Benue, Imo, Niger, Ogun and Ondo, bringing the total number of States to nineteen, from the original twelve States created by Gowon. It took another eleven years (1987) for State creation exercise to be undertaken in the country. That was under the regime of Ibrahim Babangida (1985 - 1993).

In 1987, Babangida created two States namely, Akwa Ibom and Katsina. He also created nine additional States in 1991. These were: Abia, Enugu, Delta, Jigawa, Kebbi, Osun, Kogi, Taraba and Yobe. It is instructive to note that Akwa Ibom State was carved out from Cross River State, while Katsina State was created from Kaduna State. Similarly, Adamawa and Taraba States were carved out from the former Gongola State, and Enugu State out of Anambra State, while Edo and Delta States replaced the old Bendel State. Also, Yobe State was created from Borno State, and Jigawa out of Kano State, while Kebbi and Osun States were carved out from Sokoto and Oyo States respectively. Kogi State came from Kwara and Benue States. Altogether, there were thirty (30) States by 1991. Sani Abacha became Nigeria's next military Head of State in 1993 after ousting the Ernest Shonekan-led Interim National Government (ING). Due to stringent agitations for more States, Abacha set up the National Constitutional Conference (NCC) which recommended, among other things, the creation of new States. Thus, on October 1, 1996, he created six additional States namely, Ebonyi (from Abia and Enugu States), Bayelsa (from Rivers State), Nasarawa (from Plateau State), Gombe (from Bauchi), and Ekiti (from Ondo). Arranged in an alphabetical order, year of creation, and the rulers that created them, the States created over the years are:

American Research Journal of Humanities and Social Sciences 
Table 1

STATES CREATED IN NIGERIA, 1967-1996

\begin{tabular}{|c|c|c|c|c|}
\hline $\begin{array}{c}\text { Yakubu } \\
\text { Gowon, 1967 }\end{array}$ & $\begin{array}{c}\text { Murtala } \\
\text { Mohammed, 1976 }\end{array}$ & $\begin{array}{c}\text { Ibrahim } \\
\text { Babangida, 1987 }\end{array}$ & $\begin{array}{c}\text { Ibrahim } \\
\text { Babangida, 1991 }\end{array}$ & $\begin{array}{c}\text { Sani } \\
\text { Abacha, 1996 }\end{array}$ \\
\hline East Central & Anambra & Akwa Ibom & Abia & Bayelsa \\
\hline Benue-Plateau & Bauchi & Katsina & Delta & Ebonyi \\
\hline Kano State & Benue & & Jigawa & Kkiti \\
\hline Kwara State & Borno & & Kebbi & Osun \\
\hline Lagos State & Gongola & & Kogi & Tarabara \\
\hline Mid-Western & Imo & & Yobe & \\
\hline North-Eastern & Niger & & \\
\hline North-Central & Ogun & & \\
\hline North-Western & Ondo & & \\
\hline Rivers State & Oyo & & \\
\hline South-Eastern & Plateau & & \\
\hline Western State & Sokoto & & & \\
\hline
\end{tabular}

Thus, there are currently a total of thirty-six States in Nigeria. These are: Abia, Adamawa, Akwa Ibom, Anambra, Bauchi, Bayelsa, Benue, Borno, Cross River, Delta, Ebonyi, Edo, Ekiti, Enugu, Gombe, Imo, Jigawa, Kaduna, Kano, Katsina, Kebbi, Kogi, Kwara, Lagos, Nasarawa, Niger, Ogun, Ondo, Osun, Oyo, Plateau, Rivers, Sokoto, Taraba, Yobe, and Zamfara.

\section{THE POLITICS OF STATE CREATION}

Ordinarily, the creation of States in Nigeria was anchored, ostensibly, on the need to extend governance closer to the people and to allay the age-long fears of some ethnic groups over the over-bearing influence of their ethnically more populous neighbours. For instance, and as has been previously stated, ethnic minorities in the former eastern region started agitating for a separate State or region way back in the 1950s. Exponents of State creation also argued that such exercises will engender development and check regional economic disparities as well as ensure equality in both political participation and the sharing of federal government resources (Adejuyibe, 1980: 199-202). However, opponents of state creation, such as former President Shehu Shagari saw such an exercise as unnecessary. This was because of the long-term consequences. For instance, it was argued that State creation would not only impede development by draining the limited resources of the federal government, but would also encourage laziness on the part of the States, and conspicuous consumption among big-time contractors (Shagari, 1996). Also, given Nigeria's heterogeneous nature, it has been contended that the idea of State creation would constitute an unnecessary distraction from the task of government because of the unending competition for the resources of the Nigerian State which, more or less, has as its basis, ethnically-defined constituencies (Suberu, 1998: 277). In other words, the position of opponents of State creation is that rather than engender nation-building and national integration, such an exercise will continue to generate centrifugal challenges instead of encouraging national unity and patriotism. In particular, Nigeria's federal structure has been blamed for the agitation for State creation. This is because of federal monopoly of national resources and the consequent distributive approach in federal-state relations. Put differently, the federal government's appropriation and unilateral disbursement of funds to States has made the agitation for more States a constant refrain by those who feel that they are not getting enough, thus making true the words of Rotimi Suberu that, "the pervasive influence of the norm of inter-unit equality is also reflected in the practice of providing equal federal financial aid to new States" (Ibid, 279). Therefore, the more States the federal government creates, the more the financial burden on it, and the less the attention likely to be paid to issues relating to national development. 
There are also arguments that the creation of States in Nigeria over the years had been informed more by political considerations than any other factor. According to this school of thought, the federal government has been led, since 1967, mostly by military officers from the former northern region which is both predominantly Hausa-Fulani and Muslim. Since all States creation exercises have so far been undertaken by military regimes, the north has been favoured over and above the south (made up of the former eastern and western regions). For instance, in the 1967 exercise, the former northern region was split into six states (Benue-Plateau, Kano, NorthCentral, North-Eastern, and North-Western States), whereas the former western region had only the Western and Lagos States and a share in Kwara State (Ofoeze, 2009: 212). The former eastern region had three States, namely East Central, Rivers and South-Eastern States. As a matter of fact, it has been argued that the creation of Rivers and South-Eastern States by Gowon was intended specifically to break the Igbo by turning them into a minority in the former eastern region vis-à-vis the ethnic minorities who had two States as against one for the more populous Igbo (Ikejiani-Clark, 2002: 629). Similarly, Murtala Mohammed gave seven States to the former northern region in 1976, three more to the former western region, and only two to the former eastern region. The trend of favouring the north was sustained in the 1987, 1991 and 1996 States creation exercises by the regimes of Ibrahim Babangida and Sani Abacha respectively. In all, today, out of the thirty six States in Nigeria, the predominantly Hausa-Fulani Muslim north has fourteen States, while ethnic minorities in the north have five; the Yoruba have six States, with stakes in two, while the Igbo have five States, just one State more than the ethnic minorities in the former eastern region.

Nigeria's federal system is such that the centre has an overwhelming control over the financial resources of the country. The allocation of these resources is also based on the number of States and local governments. The former northern region has more States and local government areas than the former eastern and western regions combined. Since the bulk of Nigeria's financial resources are generated from crude oil in the former eastern region, there have been cries of marginalisation and calls for the adoption of true federalism from the ethnic groups within that region. In the long run, the politicisation of State creation has deepened inter-ethnic and inter-regional animosities, especially between those who feel short-changed and those who believe that all is fair.

The introduction and legitimisation of such criteria as the quota system and the federal character principle, as well as the use of land mass and number of local government areas in the allocation of national resources have, in no small measure, exacerbated the agitation for more States and local government areas, especially in the southern part of the country. The argument appears to be, as earlier stated, that the former northern region has been unduly favoured in all the State creation exercises. Thus, there have been cries of internal colonisation from the domination of Nigerians by the northern Nigerian oligarchy, a situation which has favoured the flowering of new dimensions of inter-ethnic and inter-religious conflicts in the country. Because they have been in control of the federal government for most of Nigeria's independence, the northern Nigerian oligarchy has been accused of using its advantage to alienate and subdue other Nigerians (Ayoade, 1998: 106). For instance, since the end of the Nigeria-Biafra war in 1970, political appointments as well as the provision of social amenities and infrastructures by the Federal Government have remained skewed in favour of the north. Similarly, the Federal Character Principle has resulted in the discarding of merit in recruitments into and promotions in the federal civil service and federal parastatals. The story is basically the same in the admission of students into federal government-owned secondary and tertiary institutions where merit is often sacrificed on the altar of federal character in order to enable some so-called educationally-disadvantaged groups catch up with those considered better off. The result, over time, has been the continued contestations and struggles between the various ethnic groups for more States and therefore, better access to the country's financial resources. This is so because, as previously observed, resource allocations from the "almighty" Federal Government are based on the number of States and local government areas.

Most importantly and as rightly observed, the creation of States was a direct outcome of the attempt to redress the north-south regional imbalance but this has led to the domination of the south by the north, a situation 
which has made the north to literally determine the political fate of all Nigerians (Ibid, 108). Among other things, the legitimisation of the principle of federal character has not engendered, in any discernible and acceptable manner, fair and equitable treatment of all Nigerians. Rather, it has endangered national integration efforts because of the continued emphasis on State of origin and ethno-linguistic affiliations in appointments into federal government-owned establishments, agencies and institutions. In the words of J. A. A. Ayoade, "... the operationalisation of the Federal Character Principle has tended more to differentiate than to integrate" (Ibid). This is because of the obvious fact that the unfair distribution of the nation's financial resources and infrastructural development has resulted in feelings of marginalisation, deprivation and domination among the people of the former eastern region, especially those of the Niger Delta whose crude oil-bearing lands have suffered environmental degradation over the years.

\section{A COST-BENEFIT ANALYSIS OF STATE CREATION}

A pertinent question to ask is whether the various States creation exercises have, in any appreciable manner, promoted economic development in Nigeria. In other words, has the creation of states positively impacted on the economic and social wellbeing of the vast majority of Nigerians? This is indeed a difficult question to answer. Nonetheless, the creation of States has benefited the masses psychologically but materially, it is the elite that are the major beneficiaries because they are the ones that get appointed into juicy political offices and get multi-million contracts. In the end, the social and economic conditions of the masses have either stagnated or worsened because of corruption on the part of the elite. This also, according to Suberu (1998: 278), is because:

While distributive pressures lie at the roots of the clamour for new subnational units in Nigeria, the actual processes and outcome of territorial reorganizations usually reflect the interests, perceptions, calculations and manipulations of national growing elites.

In other words, although one of the reasons for the creation of States was to ensure, among other things, ethnic autonomy and development, it has had the opposite effect because the expected level of development and better quality of life for most Nigerians have remained a mirage. On the contrary, the rich have continued to get richer while the poor are getting poorer. Also, State creation and the country's fraudulent unitary federal system have combined to stymie the exploitation of the country's other economic resources. Put differently, the reliance of States on the federal government for the allocation of financial resources has had the negative consequence of such States not exploiting other sources of revenue generation. Quoting sources from the Central Bank of Nigeria (CBN), Suberu (Ibid, 280) has observed that:

...as presently constituted, only few states and local governments can provide up to 30 percent of their planned expenditures from their internal generation efforts. The statutory allocation from the federal account between 1990 and 1994 constituted, on the average, over 70 percent of the current revenues of the state governments, while internally generated revenues accounted for only 17.8 percent and the balance was by special (discretionary) grants from the federal government...

The situation has not changed, even today. According to a recent report, in 2018, the Nigerian economy realised the equivalent of $\$ 30.1$ billion ( $\mathrm{N} 1.103$ trillion) as internally generated revenue. Over seventy percent of that amount came from the south (BusinessDay, 2019). The north's contribution remains abysmally low yet the north takes at least sixty-five percent when internally-generated revenues are disbursed to States and local government areas. Thus, the north owns Nigeria just like a slave owner owns his slaves.

Ironically, when references are made to the north, the assumption seems to be that the old or former northern region is still a monolithic and homogenous entity. This is erroneous because ethnic minorities in the north are themselves, not comfortable with the overbearing influence of the Hausa-Fulani oligarchy. For instance, in the 1979 elections, some States did not join the dominant National Party of Nigeria (NPN) which was seen, more or less, as a reincarnation of the Northern People's Congress (NPC). Rather, they broke away politically 
from the core north, with present-day Plateau State voting for the Nnamdi Azikiwe-led Nigerian Peoples Party (NPP), while present-day Borno and former Gongola States voted for the Great Nigeria Peoples Party (GNPP) led by Ibrahim Waziri (Nnoli, 1980: 259-265). But as has been objectively asserted, the central objective of State creation right from the era of the Willinks' Commission of 1958 up to that of Irikefe (1975) was not necessarily because the creation of new States would lead to the speedy development of the areas agitating for such States. On the contrary, political considerations were the most important reasons for such agitations. As Okwudiba Nnoli has argued, ethnic minorities were worried and afraid that the regional governments, dominated as they were by ethnic majorities, would employ and arbitrarily use the instruments of law and order to subjugate and keep them perpetually dominated. However, it does appear, as has been previously noted, that the agitations for State creation, have in the main, been informed by the desire of the Nigerian elite in the various regions to use the country's ethnic character to create their own personal economic fiefdoms (Oguedo, 1990: 12). In other words, State creation in Nigeria has not resulted in any form of Eldorado for the vast majority of those ethnolinguistic or geographic areas supporting such exercises. As a matter of fact, it is mostly the elite in such areas that have benefited both politically and economically from State creation. The hope of political stability as a necessary outcome of State creation is yet to materialise because of the pervasive economic hardship and social instability in the country.

In terms of poverty alleviation, the creation of States has only marginally addressed the issue. For instance, Nigeria is ranked $157^{\text {th }}$ out of 189 countries on the Human Development Index (HDI) as at 2019. Thus, the overall socioeconomic condition in the country is still a cause for concern, while regional disparities are indeed, very alarming (Nnoli, ibid: 258). About 70 percent of Nigerians live below the poverty line as at 2019: people who earn less than one US dollar per day. The dangers inherent in this are obvious: hunger and poverty breed a variety of anti-social activities such as drug addiction, banditry, and national insecurity. The poor standard of living, along with ethnicity and statism, has also not worked in favour of occupational mobility. Since the economic expectations of some ethnic groups have not really been met through the creation of States, their members have come to see Nigerians from other States, especially professionals, as unwelcome competitors for the opportunities available in such States. Thus, sentimental attachments to States and the fear of competition from members of other ethnic groups have sometimes snowballed into violent conflicts in parts of the country. These have often been instigated by the elite, who are often desperate to ensure their economic and political survival by trying to whip up emotions and hysteria on the perceived domination of their areas by people considered as outsiders or non-indigenes (Dangote, 2019).

\section{CONCLUSION}

Calls or clamours for the creation of States over the years have resulted in the balkanisation of Nigeria. There have been both beneficiaries and casualties. The major ethnic groups have benefited from the various State creation exercises, vis-à-vis some of their ethnic minority counterparts. This has been so because of the emphasis on population as an important criterion. It has continued to fuel the agitation for more States in order to redress perceived deprivation by those ethnic minorities who feel that they have been short-changed in the devolution of federal revenues. In the same vein, there have been obvious discriminatory practices in the creation of States since 1967. For instance, in the 1976 exercise, the Igbo who are not less populous than the Yoruba had to contend with only two States as against the latter's four (including Lagos). The trend has continued ever since. It is true that the use of ethnicity as a criterion for the creation of States may be detrimental to national unity. Yet, there is obvious injustice when a particular ethnic group is clearly marked out for humiliation. Presently, the Igbo in the south-east geopolitical zone have five States as against six in the south-west, north-east, southsouth, and north-central geopolitical zones, and seven in the north-west geopolitical zone.

As a matter of fact, the feelings of alienation and marginalisation of the Igbo and the ethnic minorities of the Niger Delta have cast aspersions on the workability of the Nigerian brand of federalism. This is because of the fact that the bulk of the country's foreign exchange earnings come from the export of crude oil. This resource 
is obtained from the south-east and south-south geopolitical zones. Yet, in terms of allocation of the revenues generated and the location of federal government-owned capital projects, the two geopolitical zones do not receive any special treatment. The mushrooming of militant ethnic separatist groups is one important outcome of this official neglect of the goose that lays the golden egg, as it were. In addition, most of the States, especially in the north, are not viable and can hardly survive without the monthly allocations from the federal government. The elite who are the major beneficiaries of the various State creation exercises have exploited the poverty and ignorance of the people to stir up inter-ethnic ill-feelings. This is to cover up their failure to satisfy their peoples' basic human and material needs by stimulating production in the economic sector, especially agriculture and manufacturing. The elite are more interested in the distributive aspects and the tertiary sector of the economy. One way out of the quagmire is the unbundling or restructuring of Nigeria's federal system. This will make the States to recognise and mobilise forces to internally generate enough revenue for executing people-oriented projects instead of running cup in hand to the federal government to receive financial hand-outs every month. In particular, a restructured federal system would devolve more powers to the component units. It will also ensure the stability of the country by reducing cries of alienation, discrimination, and marginalisation and the attendant negative consequences.

When control over the federal government becomes less attractive because its hold on the bulk of national resources has been reduced, State and local government areas would be in a better position to render more and sustainable services to the people. As presently constituted, Nigeria's federal system has failed even with the creation of so many States to engender national unity. If anything, statism has, like the federal character and quota system principles, polarised Nigerians along ethnic, regional and religious lines. In spite of Nigeria's huge population and her federal structure, therefore, the country does not seem, at least from the political and economic points of view, to be better off than her smaller neighbours in fundamental respects. Poverty and illiteracy have continued, and may continue to deny the overwhelming majority of the citizens the opportunity of playing any meaningful part in the distribution of sources of power and enjoying the derivable benefits (Bretton, 1973: 42). Therefore, an important antidote to Nigeria's challenges of statehood is a critical reappraisal of current economic and political structures and the adoption of political and development strategies that will synergise the citizens' interests with those of their country.

\section{REFERENCES}

1. Adejuyibe, O. Creation of States in Nigeria. Lagos: Federal Government Press, 1980.

2. Awolowo, O. Path to Nigerian Freedom. London: Faber and Faber, 1947.

3. Ayoade, J. A. A. "The Federal Character Principle and the Search for National Integration", in Amuwo, K., Agbaje, A., Suberu, R., and Héraul, G. (eds), Federalism and Political Restructuring in Nigeria. Ibadan: Spectrum Books Ltd, 1998.

4. Azikiwe, N. "Creation of more States in Nigeria." The Senator. Vol. 1, No. 1, 25, 1943.

5. Bretton, H. L. Power and Politics in Africa. London: Longman Group Ltd, 1973.

6. BusinessDay Newspaper, May 16, 2019.

7. Dangote, A. Speech at the Fourth Edition of the Kaduna Investment Summit (Kadinvest, 40) held in Kaduna on Wednesday, April 3, 2019. Available at: http://www.torinews.com, April 4, 2019. Accessed: $4^{\text {th }}$ December 2019.

8. Ellah, E. J. Nigeria and States Creation. Based on "the Unfinished Nation." Port Harcourt: Chief T. W. Ellah, Sons and Co., Ltd., 1983.

American Research Journal of Humanities and Social Sciences 
9. Ikejiani-Clark, M. I. O. "The Igbo in Contemporary Nigeria", in Ofomata, G. E. K. (ed), A Survey of the Igbo Nation. Onitsha: Africana First Publishers Ltd, 2002.

10. Imoagene, S. O. "Post-war Ethnic Relations in Nigeria" in Van den Benghe, P. L. (ed) Race and Ethnicity in Africa. Nairobi: East African Publishing House, 1975.

11. Nnoli, O. Ethnic Politics in Nigeria. Enugu: Fourth Dimension Publishers, 1980.

12. Ofoeze, H. G. A. The Nigerian State and Human Rights of the Igbo. Abakaliki: Data-Globe Nigeria, 2009.

13. Oguedo, S. "Stepping into the Minefield Struggle for National Resources Polarizes Nigerians into the North against the South." This Week, No. 161, February 12, 1990.

14. Ojiako, J. O. Nigeria: Yesterday, Today and ...? Onitsha: Africana Educational Publishers (Nig) Ltd, 1981.

15. Olusanya, G. O. "Constitutional Developments in Nigeria” in Ikime, O. (ed), Groundwork of Nigerian History. Ibadan: Heinemann Educational Books, 1999.

16. Shagari, S. "The Time for Muddling Through is Over." Speech made at the Usman Dan Fodio University, Sokoto, on January 13, 1996.

17. Suberu, R. "States Creation and the Political Economy of Nigerian Federalism", in Amuwo, K., Agbaje, A., Suberu, R., and Héraul, G. (eds), Federalism and Political Restructuring in Nigeria. Ibadan: Spectrum Books Ltd, 1998.

Citation: Ejitu N. Ota, Chinyere S. Ecoma, Chiemela Godwin Wambu "CREATION OF STATES IN NIGERIA, 1967-1996: DECONSTRUCTING THE HISTORY AND POLITICS". $\quad$ American Research Journal of Humanities and Social Sciences, Vol 6, no. 1, 2020, pp. 1-8.

Copyright (c) 2020 Ota EN, et al, This is an open access article distributed under the Creative Commons Attribution License, which permits unrestricted use, distribution, and reproduction in any medium, provided the original work is properly cited. 